\title{
SURVIVAL GUIDE 2.0
}

\section{HJÄLP! JAG FÅR INTE TAG I ARTIKELN JAG LETAR EFTER!}

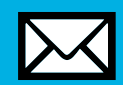

Kontakta

författaren
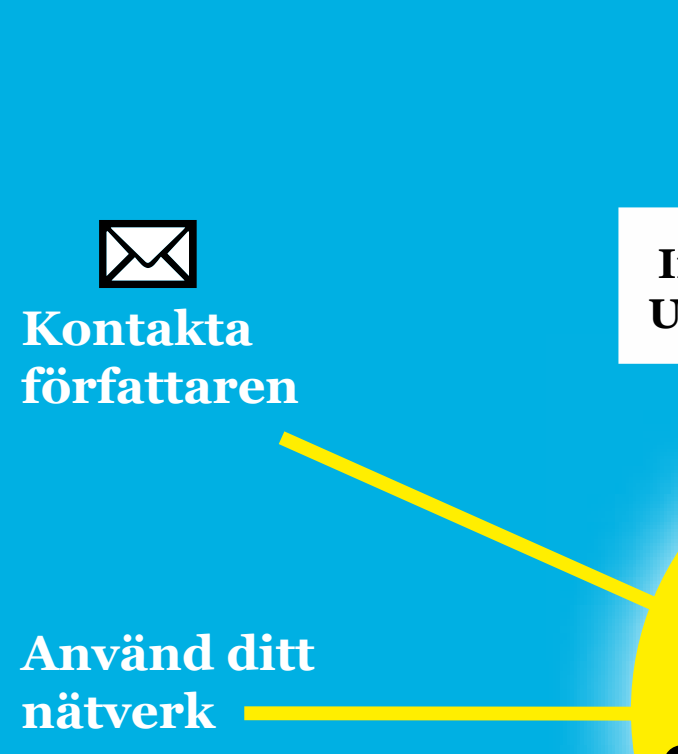

\section{UniSearch}

Google

\section{Google Scholar}

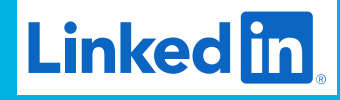

\section{ResearchGate}

\section{Sociala medier}

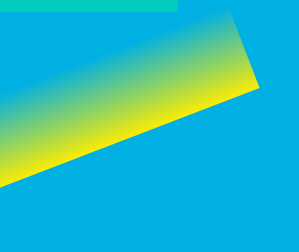

\section{Fjärrlån}
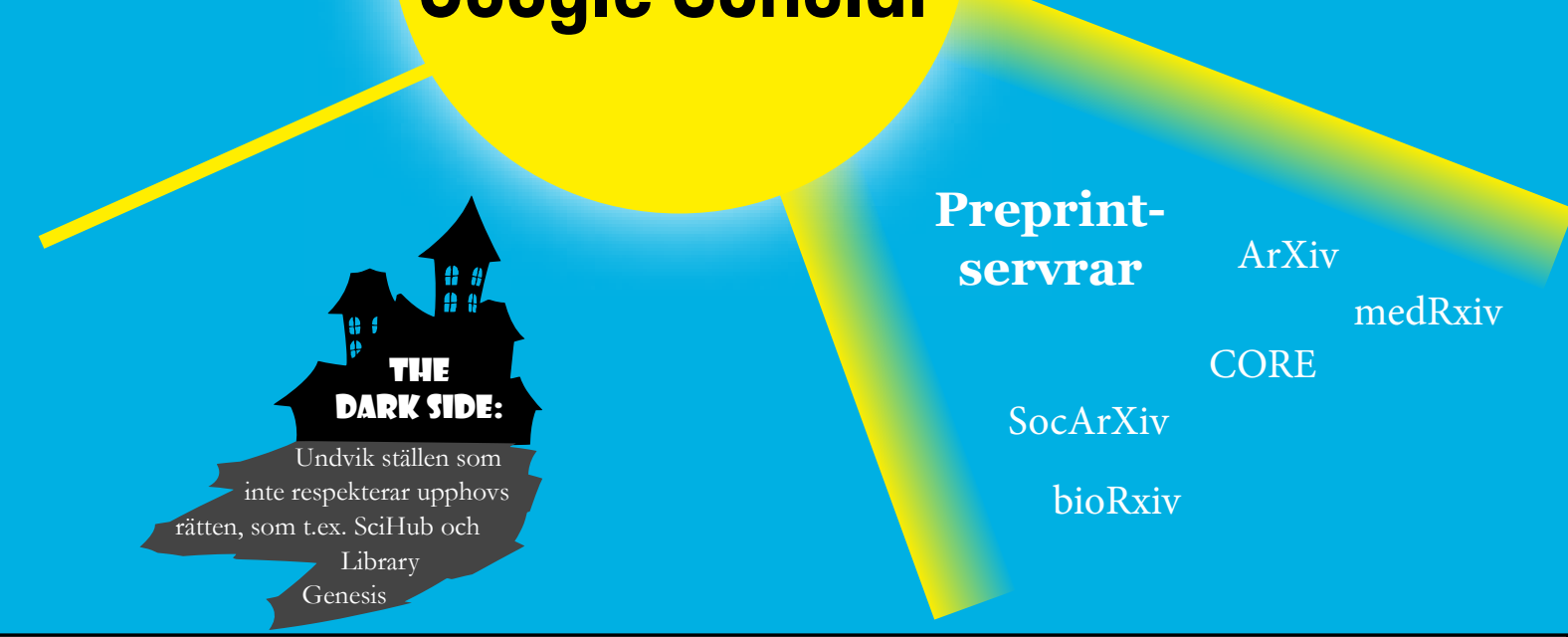

Välkommen till Survival Guide 2.o! Sedan vi gjorde första versionen av Survival Guide 2017 har mycket hänt. Idag är det till exempel mycket vanligare att artiklar publiceras med öppen tillgång (open access) och inte kräver biblioteksprenumerationer. För de tillfällen då det trots allt är svårt att hitta en viss artikel finns Survival Guide.

Unpaywall går att installera som plug-in i din webbläsare. Den Mejla direkt till författaren! Förmodligen är hen intresserad av hjälper dig att snabbt hitta open access-versioner av publikationer. Andra liknande tjänster är Google Scholar Button och Open Access Button.

Via ResearchGate, och i viss mån LinkedIn, kan man ladda ner och efterfråga artiklar och få kontakt med författare.

Unisearch: UBs sökmotor ger direkt tillgång till resurser som biblioteket prenumererar på (inklusive e-böcker som är svårt att kommer åt annars) och även fritt tillgängligt innehåll. Missa inte PubMedCentral! 